\section{International Scientific Journal \\ Theoretical \& Applied Science}

p-ISSN: 2308-4944 (print) e-ISSN: 2409-0085 (online)

Year: $2014 \quad$ Issue: $10 \quad$ Volume: 18

Published: $30.10 .2014 \quad$ http://www.T-Science.org

SECTION 23. Agriculture. Agronomy. The technique.
Bair Batoevich Tsybenov senior research scientist,

State Scientific Institute «Buryat Research Institute of Agriculture» of Russian Academy of Agricultural Sciences, Ulan-Ude tzbair@yandex.ru

Alexandr Semenovich Biltuyev senior research scientist,

State Scientific Institute «Buryat Research Institute of Agriculture» of Russian Academy of Agricultural Sciences, Ulan-Ude

\title{
GLUTEN CONTENT AT THE DIFFERENT SOWING DATE OF SPRING WHEAT IN THE DRY STEPPE CONDITIONS OF BURYATIA
}

Abstract: Here are the results of the effect of sowing date on wet gluten content in grain of spring wheat. Key words: spring wheat; sowing date; variety; quality; gluten.

Language: Russian

Citation: Tsybenov BB, Biltuyev AS (2014) GLUTEN CONTENT AT THE DIFFERENT SOWING DATE OF SPRING WHEAT IN THE DRY STEPPE CONDITIONS OF BURYATIA. ISJ Theoretical \& Applied Science 10 (18): 33-36. doi: http://dx.doi.org/10.15863/TAS.2014.10.18.8

\section{СОДЕРЖАНИЕ КЛЕЙКОВИНЫ ПРИ РАЗНЫХ СРОКАХ ПОСЕВА ЯРОВОЙ ПШЕНИЦЫ В УСЛОВИЯХ СУХОЙ СТЕПИ БУРЯТИИ}

Аннотация: Приводятся результаты исследований влияния сроков посева на содержание сырой клейковины в зерне яровой мягкой пиеницы.

Ключевые слова: яровая пшеница; срок посева; сорт; качество; клейковина.

\section{Введение}

Содержание клейковины в зерне пшеницы и ее качество являются одними из важнейших показателей, характеризующих качество зерна. На количество клейковины в зерне яровой пшеницы, прежде всего, влияют экологические условия выращивания культуры. Значительная роль в производстве высококачественного зерна принадлежит сорту, т.к. качество клейковины это наследственный признак, и технологии его возделывания [1; 9]. Исследованиями [4] также было установлено, что сортовые особенности оказывают существенное влияние на темпы формирования клейковины в зерне яровой пшеницы. Повышение температуры и понижение относительной влажности воздуха в период налива зерна повышает содержание белка и сырой клейковины [5], причем это действие усиливается на фоне недостаточной влажности почвы. В суховейном зерне содержание белка и сырой клейковины также значительно повышается.

\section{Методика и условия исследований}

Исследования проводили в 2006-2008 гг. в сухостепной зоне Бурятии на опытном поле
Бурятской ГСХА им. В.Р. Филиппова.

Цель исследований - изучить влияние сроков посева (ранний - 5-8 мая; средний - 15-18 мая; поздний - 25-28 мая) на изменение содержания клейковины в зерне яровой пшеницы сортов Селенга, Бурятская остистая, Арюна, Тулайковская степная и Новосибирская 29.

Почвенный покров опытного стационара представлен каштановой мучнисто-карбонатной легкосуглинистой почвой с низким содержанием гумуса $(1,28 \%)$.

Опыт размещался по чистому пару в 4кратной повторности, учетная площадь делянок - 56 м², норма высева - 4 млн. всхожих семян/га. Уборка - однофазная, комбайном Sampo-500. Урожай приведен к стандартной (14\%) влажности и 100\%-ной чистоте. Методика определений и учетов - общепринятая для государственного сортоиспытания [6]. Статистическая обработка данных проводилась по [3], а также с помощью пакета анализа данных программ Excel и Snedecor.

Количество атмосферных осадков и температура воздуха учитывались АМC п. 
Иволгинск, расположенного в 5 км от опытного участка. За период вегетации растений яровой пшеницы в течение трех лет наблюдалось в целом нехарактерное распределение атмосферных осадков на фоне повышенной теплообеспеченности. Наиболее благоприятными по влагообеспеченности вегетационного периода были 2006 и 2008 гг. Весенний период в эти годы был засушливым, а июнь в отличие от многолетних показателей отличался избыточным увлажнением и максимальными показателями ГТК - 1,66 и 1,64, соответственно. В 2007 г наблюдались минимальные значения ГТК в июле и августе $(0,38$ и 0,32$)$, что объясняется наименьшим количеством осадков за эти месяца при максимальной теплообеспеченности.

\section{Результаты исследований}

Метеорологические условия в годы проведения наших исследований оказали значительное влияние на качество зерна. Содержание в нем сырой клейковины в среднем по годам характеризовалось как высокое. Среднесортовые показатели содержания сырой клейковины во все годы исследований указывают на преимущество среднего срока посева. Исключения наблюдались в 2007 и 2008 гг. по сортам Тулайковская степная и Селенга, а также по сорту Бурятская остистая в 2008 г. Средние показатели также свидетельствуют о том, что все сорта по содержанию клейковины превышали контроль Селенга, кроме сорта Арюна при позднем сроке посева.

В целом за весь период исследований лучшие условия для формирования клейковины сложились в 2006 г., при этом максимальное ее содержание было отмечено у сортов Бурятская остистая и Арюна (44,0 и 42,0\%, соответственно). Наименьшие показатели были отмечены в 2007 г. у сорта Селенга $(28,6 \%)$ при среднем сроке посева и в 2008 г. у сорта Тулайковская степная $(29,0 \%)$ при позднем сроке посева (табл. 1).

В условиях 2008 г. содержание сырой клейковины у сортов в зависимости от сроков посева носило несколько иной характер. Сорта Арюна, Тулайковская степная и Новосибирская 29 значительно уступали контролю при всех сроках посева, сорт Бурятская остистая - только при позднем сроке посева.

В исследованиях [8] показано, что зерно лучшего качества формируется при ранних сроках посева. При позднем сроке посева урожай зерна и его качество снижаются. Также было установлено [7], что ранние сроки посева способствуют более эффективному использованию продуктивной влаги (на 20-22\%) и увеличению (на 0,8-7,3\%) содержания в зерне клейковины.

Дисперсионный анализ результатов наших исследований показал, что в среднем за время их проведения различия между вариантами опыта были достоверными. При анализе показателя по фактору В (сорт) выделялись сорта Бурятская остистая, Арюна и Новосибирская 29, у которых содержание сырой клейковины существенно превышало контроль при среднем сроке посева. По фактору А (срок посева) также выделялись сорта Бурятская остистая и Арюна, у которых при позднем сроке посева содержание сырой клейковины достоверно снижалось.

Содержание сырой клейковины у сортов яровой пшеницы

Таблица 1 при разных сроках посева, \%, 2006-2008 гг.

\begin{tabular}{|c|c|c|c|c|c|c|}
\hline \multirow{2}{*}{$\begin{array}{c}\text { Срок посева } \\
\text { (фактор А) }\end{array}$} & \multirow{2}{*}{$\begin{array}{c}\text { Сорт } \\
\text { (фактор В) }\end{array}$} & \multicolumn{3}{|c|}{ Год } & \multirow[t]{2}{*}{$\mathrm{M} \pm \mathrm{m}$} & \multirow[t]{2}{*}{$\mathrm{V}, \%$} \\
\hline & & 2006 & 2007 & 2008 & & \\
\hline \multirow{5}{*}{ ранний } & Селенга (контроль) & 35,6 & 31,2 & 34,8 & $33,9 \pm 1,1$ & 5,7 \\
\hline & Бурятская остистая & 40,0 & 31,9 & 35,4 & $35,8 \pm 1,9$ & 9,3 \\
\hline & Арюна & 40,0 & 33,0 & 30,1 & $34,4 \pm 2,4$ & 12,1 \\
\hline & Тулайковская степная & 37,4 & 34,1 & 30,4 & $34,0 \pm 1,7$ & 8,4 \\
\hline & Новосибирская 29 & 38,2 & 34,0 & 31,0 & $34,4 \pm 1,7$ & 8,6 \\
\hline \multicolumn{2}{|c|}{ Среднесортовое по сроку посева } & 38,2 & 32,8 & 32,3 & $34,5 \pm 1,5$ & 7,7 \\
\hline \multirow{5}{*}{$\begin{array}{c}\text { средний } \\
\text { (контроль) }\end{array}$} & Селенга (контроль) & 36,4 & 28,6 & 34,6 & $33,2 \pm 1,9$ & 10,0 \\
\hline & Бурятская остистая & 44,0 & 31,9 & 36,0 & $37,3 \pm 2,9$ & 13,5 \\
\hline & Арюна & 42,0 & 33,7 & 31,3 & $35,7 \pm 2,6$ & 12,9 \\
\hline & Тулайковская степная & 40,0 & 32,1 & 34,4 & $35,5 \pm 1,9$ & 9,3 \\
\hline & Новосибирская 29 & 39,0 & 36,8 & 31,2 & $35,7 \pm 1,9$ & 9,2 \\
\hline \multicolumn{2}{|c|}{ Среднесортовое по сроку посева } & 40,3 & 32,6 & 33,5 & $35,5 \pm 2,0$ & 9,6 \\
\hline \multirow[b]{3}{*}{ поздний } & Селенга (контроль) & 34,4 & 31,1 & 33,7 & $33,1 \pm 0,8$ & 4,3 \\
\hline & Бурятская остистая & 40,0 & 33,6 & 31,5 & $35,0 \pm 2,1$ & 10,3 \\
\hline & Арюна & 38,0 & 30,4 & 30,3 & $32,9 \pm 2,1$ & 11,0 \\
\hline
\end{tabular}




\begin{tabular}{|c|c|c|c|c|c|c|}
\hline & Тулайковская степная & 38,4 & 34,8 & 29,0 & $34,1 \pm 2,2$ & 11,4 \\
\hline & Новосибирская 29 & 36,5 & 35,4 & 32,3 & $34,7 \pm 1,0$ & 5,1 \\
\hline Среднесо & ртовое по сроку посева & 37,5 & 33,1 & 31,4 & $34,0 \pm 1,5$ & 7,6 \\
\hline $\begin{array}{r}\mathrm{HCP}(\mathrm{y} \\
\text { для фа }\end{array}$ & $\begin{array}{l}\text { ровень значимости) } \\
\text { ктора А - }\end{array}$ & & & $\begin{array}{l}\text { акто } \\
\text { заим }\end{array}$ & твия AB - & $\begin{array}{l}2,4 \\
4,2\end{array}$ \\
\hline
\end{tabular}

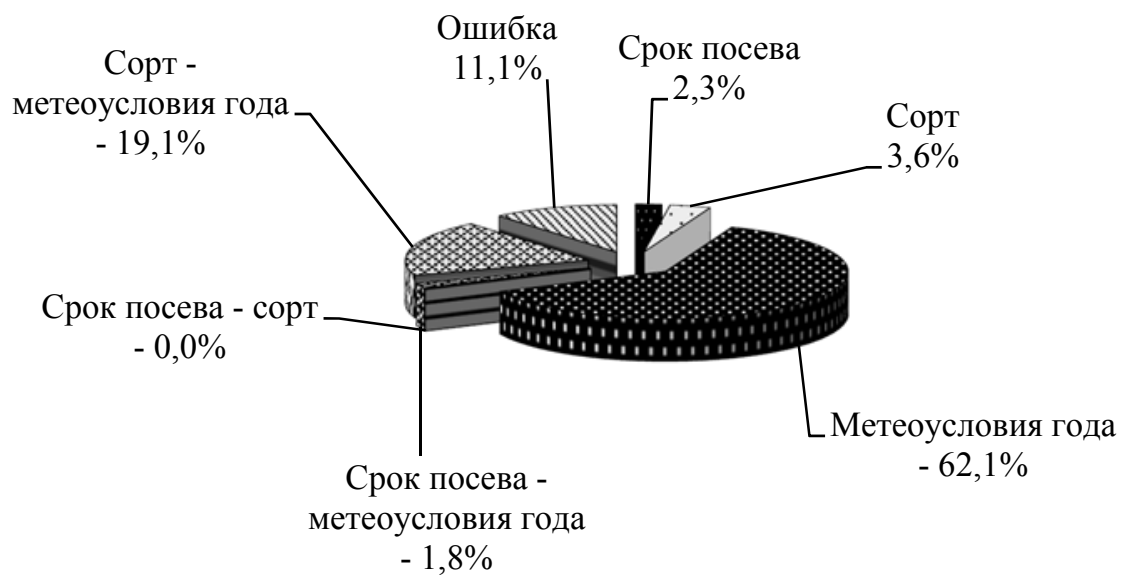

\section{Рисунок 1 - Доля влияния различных факторов на изменчивость содержания сырой клейковины, 2006-2008 гг.}

В среднем за три года на изменчивость содержания сырой клейковины в зерне яровой пшеницы большее влияние оказывали метеорологические условия года и генотипсредовые взаимодействия (рис. 1). Влияние сорта и сроков посева было незначительным и составляло лишь 3,6 и 2,3\%, соответственно.

Парное взаимодействие этих факторов, а также взаимодействие в системе «срок посева метеоусловия года» носили аддитивный характер.

Таким образом, результаты нашей работы согласуются с результатами исследований [2; 10], где сделан вывод о том, что на варьирование технологических показателей качества зерна, в том числе и на содержание клейковины, основное влияние оказывают факторы условий среды (годы, местности). При этом по содержанию клейковины достоверными были сорто-средовые взаимодействия, значительные величины которых свидетельствовали о нестабильности сортов по данному показателю даже в условиях одной местности.

\section{Заключение}

Наибольшее количество клейковины у новых районированных сортов Бурятская остистая, Арюна, Новосибирская 29 и Тулайковская степная в условиях южной сухой степи Бурятии формируется при их посеве во второй декаде мая. Данный срок посева обеспечивает достоверную прибавку в содержании сырой клейковины у первых трех из перечисленных сортов.

Сорт Селенга отличается большим содержанием клейковины при ранних сроках посева, но при этом наименьшая изменчивость $(\mathrm{V}, \%)$ данного показателя была отмечена при позднем $(4,3)$ и раннем $(5,7)$ сроках посева.

В целом за время проведения наших исследований на содержание сырой клейковины в зерне яровой пшеницы большее влияние оказывали метеорологические условия года $(62,1 \%)$ и генотип-средовые взаимодействия $(19,1 \%)$.

\section{References:}

1. Batoev BB, Dudnikova FJa, Denisenko GA, Travkina TN, Darhanova VG (1996) Formirovanie kachestva zerna $\mathrm{u}$ sortov jarovoj mjagkoj pshenicy $\mathrm{v}$ zavisimosti ot uslovij vyrashhivanija. Sb. tr. Burjatskogo NIISH SO RASHN, Vyp. VI, chast' I. pp. 28-34.

2. Bebyakin VM, Vasiljchuk NS (2000) Kak uluchitj kachestvo zerna pshenicy. AgroXXI. No. 5. pp. 20-21. 
3. Dospehov BA (1985) Metodika polevogo opyta. s osnovami statisticheskoj obrabotki rezuljtatov issledovanij. Moscow: Agropromizdat, 351.

4. Ivanenko LS (1974) Osobennosti formirovanija nekotoryh pokazatelej kachestva zerna u sortov jarovoj pshenicy. Nauch. tr. Omskogo SHI. Omsk, T. 123. pp. 78-80.

5. Kondratenko EP, Pinchuk LG, Shajdulina TE (2002) Zavisimost' nekotoryh pokazatelej kachestva zerna jarovoj pshenicy ot uslovij vyrashhivanija. Zernovoe hoz-vo. No. 7. pp. 2425.

6. (1989) Metodika gosudarstvennogo sortoispytanija sel'skohozjajstvennyh kul'tur. Moscow, Vyp. 2, 194.

7. Mingazov FF, Shamsutdinova KG, Shajhutdinov FSh, Gajnutdinov PM, Zajnullin ShA (1999) Tehnologija proizvodstva vysokokachestvennogo zerna pshenicy. Zemledelie. - 1999. - No. 4, 30.

8. Cepenko AA (1963) Vlijanie srokov seva na kachestvo semjan jarovoj pshenicy $\mathrm{v}$ lesostepi Burjatii. Selekcija i semenovodstvo. - 1963. No. 2. pp. 36-39.

9. (1998) Jarovaja pshenica v Vostochnoj Sibiri (biologija, jekologija, selekcija i semenovodstvo, tehnologija vozdelyvanija) Pod red. N.G. Vedrova; Krasnojarskij gos. agrar. unt. - Krasnojarsk, 312.

10. Nel MM, Agenbag GA, Purchase JL (2000) Sources of variation in spring wheat, Triticum aestivum L., cultivars of the Western and Southern Cape. II. Baking characteristics. S. Afr. J. Plant and Soil. 17. No. 1. pp. 40-48. 